\title{
Analisis Hukum Islam terhadap Pajak Waris dalam Pasal 2 Ayat (2) UU Nomor 20 Tahun 2000 tentang Bea Perolehan Hak Atas Tanah dan Bangunan
}

\author{
Mira Safira Fratiwi* \\ Prodi Hukum Keluarga Islam, Fakultas Syariah, Universitas Islam Bandung, \\ Indonesia. \\ *mirasafiraf@gmail.com
}

\begin{abstract}
Inheritance assets are all assets left by the heir due to his death, which have been free from religious and mundane obligations such as medical expenses when the heir is sick until his death, the cost of managing the corpse, zakat, donations or waqf that he has ever declared, or debts, ransoms and so on. However, based on the author's research, there is a legal product, namely Law Number 20 of 2000 concerning Amendments to Law Number 21 of 1997 concerning Fees for Acquiring Rights on Land and Buildings (BPHTB). One of the provisions that has just been regulated in the Law is regarding the object of inheritance as stated in Article 2 paragraph (2). Based on the description, the problem points are how the tax concept in Islamic law and positive law, and how to analyze Islamic law on Article 2 paragraph (2) of Law Number 20 of 2000 concerning BPHTB. This research is a qualitative literature research with descriptiveanalysis data processing techniques. The results of the research are that in Islamic law there is no term inherited property as a provision for tax objects, and according to Islamic law taxes are allowed to be levied on condition that the collection must be temporary if a state or Baitul Mal is experiencing a vacuum.
\end{abstract}

Keywords: Inheritance, Islamic Law, Tax of Acquiring Rights on Land and Building.

\begin{abstract}
Abstrak. Harta waris merupakan semua harta yang ditinggalkan pewaris karena wafatnya, yang telah bersih dari kewajiban-kewajiban keagamaan dan keduniaan seperti biaya keperluan pengobatan ketika pewaris sakit hingga wafatnya, biaya pengurusan jenazah, zakat, infak atau wakaf yang pernah dinyatakannya, atau hutang, tebusan dan sebagainya. Namun berdasarkan hasil penelitian penulis, terdapat produk hukum yaitu Undang-Undang Nomor 20 Tahun 2000 tentang Perubahan Atas Undang-Undang Nomor 21 Tahun 1997 tentang Bea Perolehan Hak Atas Tanah dan Bangunan (BPHTB). Salah satu ketentuan yang baru diatur di dalam Undang-Undang tersebut adalah mengenai objek warisan yang tercantum di dalam Pasal 2 ayat (2). Tujuan dari penelitian ini adalah mengetahui bagaimana konsep pajak dalam hukum Islam dan Hukum Positif, dan bagaimana analisis hukum Islam terhadap Pajak Waris dalam Pasal 2 ayat (2) Undang-Undang Nomor 20 Tahun 2000 tentang Bea Perolehan Hak Atas Tanah dan Bangunan. Penelitian ini merupakan penelitian kualitatif yang bersifat kepustakaan dengan teknik pengolahan data deskriptif-analisis. Adapun hasil penelitiannya adalah bahwa di dalam hukum Islam tidak ada istilah harta warisan dijadikan sebagai ketentuan objek pajak, dan menurut hukum Islam pajak diperbolehkan untuk dipungut dengan syarat pemungutannya harus bersifat temporer jika keadaan suatu negara atau Baitul Mal sedang mengalami kekosongan
\end{abstract}

Kata Kunci: Waris, Hukum Islam, BPHTB. 


\section{A. Pendahuluan}

Pajak dalam hukum Islam merupakan harta yang diwajibkan Allah Swt kepada kaum muslimin untuk membiayai berbagai kebutuhan dan pos-pos pengeluaran yang memang diwajibkan atas mereka, pada kondisi Baitul mal tidak ada uang atau harta. Ojeknya adalah harta selain zakat dan subyeknya kaum Muslim.

Kharakteristik pajak menurut hukum Islam yaitu pajak bersifat temporer, tidak bersifat kontinyu, dapat dihapus bila sudah tidak diperlukan, hanya boleh dipungut untuk pembiayaan yang merupakan kewajiban bagi kaum muslimin dan sebatas jumlah yang diperlukan untuk pembiayaan wajib tersebut, tidak boleh lebih, hanya dipungut dari kaum muslim yang kaya, tidak dipungut dari selainnya.

Menurut hukum waris Islam, bahwa yang dimaksud dengan harta waris adalah semua harta yang ditinggalkan pewaris karena wafatnya, yang telah bersih dari kewajiban-kewajiban keagamaan dan keduniaan yang dapat dibagi-bagi kepada para ahli waris pria atau wanita sebagaimana telah ditentukan berdasarkan kitab Al-Quran dan Hadits serta kesepakatan para Ulama.

BPHTB adalah pajak yang dikenakan atas perolehan hak atas tanah dan bangunan. Bea Perolehan Hak atas Tanah dan Bangunan (BPHTB) merupakan salah satu pajak obyektif ata pajak kebendaan dimana pajak terutang didasarkan pertama-tama pada apa yang menjadi obyek pajak baru kemudian memperhatikan siapa yang menjadi subyek pajak.

BPHTB berlandaskan hukum pada Undang-undang Nomor 21 Tahun 1997 yang menjelaskan tentang pajak yang dikenakan atas perolehan hak atas tanah dan bangunan. Berdasarkan ketentuan landasan hukum tersebut terdapat ketentuan dalam Pasal 2 ayat (1) Undang-undang Nomor 21 Tahun 1997 yang menjelaskan bahwa yang menjadi obyek pajak adalah perolehan hak atas tanah dan bangunan.

Tujuan masalah penelitian ini adalah:

1. Untuk mengetahui konsep pajak dalam Islam..

2. Untuk mengetahui konsep pajak waris Pasal 2 ayat (2) Undang-undang Nomor 20 Tahun 2000 tentang Bea Perolehan Hak atas Tanah dan Bangunan.

3. Untuk mengetahui hasil dari analisis Hukum Islam terhadap pajak waris dalam Pasal 2 ayat (2) Undang-undang Nomor 20 tahun 2000 tentang Bea Perolehan Hak atas Tanah dan Bangunan.

\section{B. Landasan Teori}

Dalam istilah bahasa Arab, pajak dikenal dengan nama Adh-Dharibah, yang artinya adalah mewajibkan, menetapkan, menentukan pungutan yang ditarik dari rakyat oleh para penarik pajak, atau merupakan beban. Pajak disebut beban karena merupakan kewajiban tambahan atas harta setelah zakat.

QS. An-Nisaa: 29:

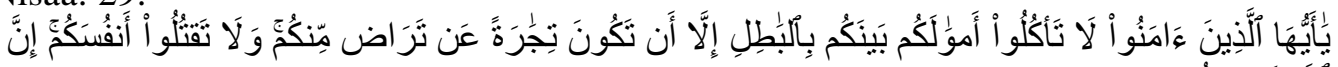

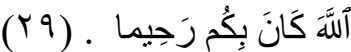

"Wahai orang-orang yang beriman, janganlah kamu saling memakan harta sesamamu dengan cara yang batil..." (QS. An-Nisaa': 29)

\section{Hasil Penelitian dan Pembahasan}

Dalam hukum Islam peralihan harta seseorang yang telah meninggal dunia kepada yang masih hidup berlaku secara sendirinya, yang dalam pengertian hukum Islam berlaku secara ijbari. Hal ini berarti bahwa perpindahan harta peninggalan pewaris kepada ahli warisnya berlaku dengan sendirinya menurut ketetapan Allah tanpa harus ada petunjuk dan pertimbangan dari pewaris maupun para ahli warisnya. Harta yang diperoleh manusia di dunia ini tidak mutlak dimiliki seterusnya karena pada suatu saat nanti mereka akan meninggal dan tentunya harta yang diperoleh akan tinggalkan dan beralih kepemilikannya kepada orang lain (ahli warisnya) yang ditinggalkan. Allah Swt berfirman pada QS. An-Nisa'ayat 33: 


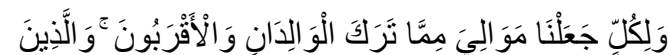

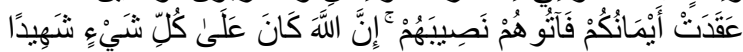

"Bagi tiap-tiap harta peninggalan dari harta yang ditinggalkan ibu bapak dan karib kerabat, Kami jadikan pewaros-pewarisnya dan (jika ada) orang-orang yang kamu telah bersumpah setia dengan mereka. Maka berilah kepada mereka bahagianya. Sesungguhnya Allah menyaksikan segala sesuatu."

Berdasarkan ayat tersebut, bahwa harta yang diperoleh setelah ditinggalkan karena telah meninggal dunia, maka akan diwariskan kepada ahli waris yang berhak yang didasarkan kepada ketentuan-ketentuan yang telah ditetapkan oleh Allah Swt dalam Al-Qur'an.

Muhammad Ali As-Shabuni memberikan definisi harta peninggalan menggunakan istilah at-tarakah (harta warisan) yaitu "apa-apa yang ditinggalkan manusia sesudah wafatnya, baik berupa harta dan hak-hak keuangan atau bukan keuangan." Dapat dipahami bahwa Muhammad Ali as-Shabuni tidak memberikan penekanan kepemilikan secara pasti, akan tetapi merumuskan harta peninggalan lebih menekankan kepada bentuk harta peninggalan tersebut.

Berdasarkan Pasal 188 Kompilasi Hukum Islam (KHI), maka pemaksaan dalam pembagian harta peninggalan dapat dilakukan oleh ahli waris apabila di antara ahli waris ada yang tidak mau melakukan pembagian. Untuk pengaturan selanjutnya yang berkaitan dengan realisasi pelaksanaan pembagian harta warisan, dijelaskan dalam Pasal 171 huruf e menyebutkan bahwa "Harta waris adalah harta bawaan ditambah bagian dari harta bersama." Artinnya bagian separuh atau seperdua dari harta bersama yang telah diatur dalam Pasal 96 ayat (1) dan Pasal 97, ditambahkan ke harta bawaan pewaris. Setelah itu, dikeluarkan untuk keperluan penggunaan yang berkaitan dengan diri pewaris termasuk pelaksanaan penguburan. Secara rinci hal ini dijelaskan lebih lanjut dalam Pasal 171 huruf e bahwa harta yang ditinggalkan pewaris sebelum dibagikan kepada ahli warisnya digunakan dulu untuk keperluan pewaris selama sakit sampai meninggalnya, biaya pengurusan jenazah, pembayaran hutang dan pemberian untuk kerabat. "Apa yang dijelaskan akhir Pasal 171 huruf e Kompilasi Hukum Islam (KHI) adalah merupakan realisasi penjelasan dan pengaturan Kompilasi Hukum Islam (KHI) Pasal 175 ayat (1) tentang kewajiban ahli waris terhadap pewaris sebagai berikut:

1. Mengurus dan menyelesaikan sampai pemakaman jenazah selesai;

2. Menyelesaikan baik hutang-hutang berupa pengobatan, perawatan, termasuk kewajiban pewaris maupun menagih piutang;

3. Menyelesaikan wasiat pewaris;

4. Membagi harta warisan di antara ahli waris yang berhak;

Kewajiban ahli waris seperti dijelaskan pada Pasal 175 ayat (1) huruf a sampai huruf c adalah dibebankan kepada harta peninggalannya yaitu harta bawaan ditambah bagian harta bersama. Sesudah terpenuhi itu semua barulah dilaksanakan kewajiban terakhir, yaitu membagi sisa harta peninggalan kepada seluruh ahli waris yang berhak. Pelaksanaan kewajiban ini hanya terbatas pada jumlah atau nilai harta peninggalan yang ditinggalkan seperti dijelaskan pada ayat (2) Pasal 175 sebagai berikut: tanggung jawab ahli waris terhadap hutang atau kewajiban pewaris hanya terbatas pada jumlah atau nilai harta peninggalannya."

Penjelasan dari alasan hukum yang telah dikemukakan, dapat kita pahami bahwa:

1. Harta waris jika dijadikan sebagai objek pajak tidak ada penjelasannya dalam AlQur'an dan Sunnah, maupun Kompilasi Hukum Islam (KHI).

2. Dalam menyelesaikan persoalan warisan, setelah pewaris meninggal dunia perpindahan harta peninggalan pewaris kepada ahli warisnya berlaku dengan sendirinya menurut ketetapan Allah tanpa harus ada petunjuk dan pertimbangan dari pewaris maupun para ahli warisnya.

3. Terdapat beberapa kewajiban ahli waris sebagai peran keluarga yang bertanggung jawab mengurus segala sesuatunya apakah pewaris meninggalkan harta atau tidak, karena merekalah yang akan menerima. Jika meninggalkan harta, mereka pula yang bertanggung jawab untuk mengurus harta tersebut sebelum harta warisan dibagikan kepada ahli waris yang lain, seperti yang telah dijelaskan pada Pasal 175 ayat (1) Kompilasi Hukum Islam.

Oleh karenanya pelaksanaan pemungutan pajak waris karena harta warisan dijadikan 
sebagai objek pajak tidak dapat dilaksanakan sebagaimana dalam KHI tidak terdapat penjelasan mengenai hal itu, dan tidak terdapat pula penjelasan di dalam Al-Qur'an dan Sunnah.

\section{Kesimpulan}

Berdasarkan uraian yang telah penulis kemukakan sebelumnya, maka dapat disimpulkan:

1. Pajak merupakan hasil ijtihad para ulama, dalam syariat Islam pajak adalah kewajiban yang dapat dilakukan secara temporer, diwajibkan oleh Ulil Amri sebagai kewajiban tambahan sesudah zakat.

Oleh karena pajak dalam Islam merupakan hasil bentuk ijtihad para ulama, maka jika kekosongan/ kekurangan Baitul mal, sedangkan pemerintah berkewajiban untuk memenuhi segala kebutuhan warganya, maka sesuai dengan kaidah maslahah mursalah lebih baik mengutamakan kemafsdatan daripada mendatangkan kemaslahatan. Karena apabila suatu negara mengalami kekosongan sangat berbahaya dari ancaman dari dalam maupun dari ancaman luar. dan dapat dihapus jika keadaan Baitul mal sudah terisi kembali, kemudian pajak dalam Islam diwajibkan hanya kepada kaum Muslim yang kaya, dan harus digunakan untuk kepentingan mereka (kaum muslim), bukan kepentingan umum, sebagai bentuk jihad kaum Muslim untuk mencegah datangnya bahaya yang lebih besar jika hal itu tidak dilakukan.

2. Akan tetapi istilah Pajak Bea Perolehan Hak Atas Tanah Dan Bangunan dimana harta waris dijadikan sebagai objek pajak, tidak terdapat atau tidak sesuai dengan ketentuan pajak yang terdapat dalam Al-Quran dan Hadis. Karena dalam Islam harta waris hanya mengatur peralihan harta dari seseorang yang telah meninggal dunia kepada ahli waris dan ketentuan berapa bagian yang akan diperoleh ahli waris, dan ketentuan sebelum di bagikan kepada para ahli warisnya, harta waris tersebut harus sudah bersih dari kewajiban-kewajiban pewaris saat pewaris hidup hingga wafatnya, seperti bersih dari biaya perwatan medis apabila pewaris sakit saat masih hidup hingga wafat, biaya pemulasaran jenazah, wasiat atau waqaf yang pernah di ikrarkan, hutang-piutang dan sebagainya. Selain pungutan yang telah disebutkan tadi tidak ada lagi kewajiban yang harus dibayar.

\section{Daftar Pustaka}

[1] Damanhur, Mewujudkan Sistem Perpajakan Perspektif Islam (Aceh: UKM Bangi)

[2] Departemen Agama RI. (1983). Al-Qur'an Dan Terjemahannya. Yayasan Penyelenggara Penerjemahan/ Penafsiran Al-Qur'an.

[3] Gazi Inayah. (2005). al-iqtishad al-islami az-Zakah wa ad-dharibah. Dirasah Muqaranah 1995, Edisi terjemah oleh Zainuddin Adnan dan Nailul Falah, Teori Komprehensif tentang Zakat dan Pajak, Yogyakarta: Tiara Wacana.

[4] Gusfahmi. (2007). Pajak Menurut Syariah. Jakarta: Rajawali Press.

[5] Hilman Hadikusumo. (1991). Hukum Waris Indonesia-Menurut Perundangan Hukum Adat, Hukum Agama Hindu, dan Islam. Bandung: Citra Aditya Bakti.

[6] http://hayatulislam.net, diakses tanggal 12 juli 2020

[7] I Gusti Agung Putra Wiryawan, dkk, Pengaturan tentang Pengenaan Pajak Bea Perolehan Hak atas Tanah dan Bangunan (BPHTB) atas Hibah dan Wasiat, Magister Kenotariatan Universitas Udayana. 